\title{
Strategic planning and place branding in a World Heritage cultural landscape: a case study of the English Lake District, UK.
}

\author{
Nicole Porter ${ }^{\text {a }}$ \\ ${ }^{a}$ Department of Architecture and Built Environment, University of Nottingham, \\ Nottingham, UK
}

Nicole.porter@nottingham.ac.uk

ORCID: https://orcid.org/0000-0001-7734-0052

Abstract

What roles do strategic planning and place branding play in the context of UNESCO World Heritage Sites (WHS)? Here it is theorised that the processes associated with the nomination and management of WHS cultural landscapes involve an integration of planning and branding, with both practices influencing the articulation of a place's universal value. A descriptive qualitative case study of the Lake District National Park, UK, traces the ways in which this cultural landscape was conceptualised, managed and communicated through the work of the Lake District National Park Authority (LDNPA) between 2006 and 2018. This illustrates how inscription of the English Lake District as a WHS in 2017 was a result of a Partnership approach to governance by the LDNPA, and that the Partnership's vision of 'sustainable development in action' responded to planning and branding imperatives. The resulting WHS inscription recognised an 'evolving' cultural landscape comprising multiple landscape identities and interests - agro-pastoral, artistic / literary, and nature conservation - which are simultaneously managed through planning and promoted through leveraging the WHS brand.

Keywords: planning, place branding, national park, partnership, World Heritage, cultural landscape 


\section{Introduction}

When a landscape receives national park or UNESCO World Heritage Site (WHS) status, this brings strict planning controls designed to conserve its special qualities. Receiving such accolades has also been perceived as having economic benefits, for example by attracting opportunities for economic growth in the form of funding, tourism and sustainable development. In short, being recognised as a place of national or universal value appears to bring multiple benefits. However, it also presents multiple challenges for governance, since it is difficult 'to reconcile protection of biodiversity and natural heritage with economic and social development' (Dinnie et al, 2012, p 454). Effective landscape governance in this context involves balancing different and often competing place identities and stakeholder interests. This can be particularly pronounced in cultural landscapes, where the qualities and identity of the place represent the 'combined work of nature and of man' (UNESCO, 2017:19).

Strategic planning (spatial policy and development controls) and place branding (marketing and communications management) both engage with place identity as part of their work; in this paper it is theorised that both practices play a part in how protected cultural landscapes are managed and marketed. ${ }^{1}$ Cultural landscapes are tangible spatial entities (topography, location, extent) and an intangible set of ideas (identities, values) whose meaning emerges within and across different professional discourses, including planning and branding. Recent literature has suggested that place branding is an

\footnotetext{
${ }^{1}$ Built environment designers, including architects, landscape architects and urban designers, are also implicated in the identification, mediation and creation of place identities. For examples of this relationship see Porter, 2016.
} 
'instrument' that may work alongside spatial planning in the context of place management, and that the synergies between them deserve further exploration (Van Assche et al, 2019). Place branding, as distinct from destination or tourism marketing, represents a holistic process that has been advocated as an effective tool for creating and managing place image (Ashworth and Kavaratzis, 2018, pp. 428 - 432). A useful distinction is that single products can be marketed, but complex entities like corporations, organisations - or landscapes - are better conceptualised as a 'network of ideas' or associations in people's minds which can be brought together as a recognisable 'brand' (Porter, 2016, pp. 37 - 38). Advocates argue that place brands can use place identity to 'further other desirable processes, whether financial investment, changes in user behaviour or generating political capital' (Kavaratzis, 2005, p 334). Strategic planning similarly encompasses 'presenting a comprehensive vision of the future' of places (Ogilvy, cited in Oliveira, 2016, p 50). Compared to traditional/ statutory planning, which is broadly characterised by rationally-based regulation, master planning and land-use control, strategic planning encompasses a more dynamic and visionary cooperative process of socio-spatial and economic change (Oliveira,2006, pp. 50 - 52).

It has been theorised that aligning or integrating strategic planning and place branding within spatial governance processes could bring together common goals (Van Assche et al, 2019). From a practical perspective, aligning branding with spatial planning provides greater chance of the 'product' (place) matching the promotional message (brand communication):

[the] branding component should not be isolated as a series of disembodied logos, design features and straplines which divorces product promotion from product creation and management. It needs to be embedded in a wider place marketing 
and place management programme that may well include much conventional planning actions and physical improvements (Ashworth and Kavaratzis, 2018: 435).

Oliveira and Ashworth theorise an even deeper alignment, asserting that planning / branding integration 'supports visionary realignment and structural change [...] social inclusion and cohesion, encourages political engagement [and...] reinforces place identification' amongst other benefits (2017, p. 26).

To test these theoretical propositions it is necessary to situate planning and branding within specific places, each with their own histories, institutional structures and dynamics. As Ashworth and Kavaratzis assert, 'it is a particular necessity to use practical examples and case studies in order to reflect more on the theoretical underpinnings of place branding' (2018: pp. 437) in relation to the strategic planning of places. A particular gap in knowledge exists in terms of planning and branding relationships at the regional landscape scale (Oliveira and Ashworth, 2017). For decades, place branding has been utilised as an instrument of urban public administration alongside entrepreneurial city governance (Ashworth \& Kavaratzis, 2018, pp. 427). However, the way it has been used in non-urban settings at a regional scale is less well known.

To examine the extent to which planning and branding processes align when governing protected cultural landscapes, this paper focuses on contemporary governance within the Lake District National Park, UK. First, literature and policies relating to protected cultural landscapes are reviewed. The Lake District case study follows, illustrating how planning and branding practices have developed over time in response to a specific landscape history and contemporary circumstances. 


\section{Managing and marketing protected cultural landscapes}

\section{Spatial planning and protected cultural landscapes}

In the UK, national park designation represents the highest possible level of landscape protection. The Environment Act 1995 sets out the current dual statutory purposes of national parks in England; 'to conserve and enhance the natural beauty, wildlife and cultural heritage of the area' and 'to promote opportunities for the understanding and enjoyment of the parks' special qualities by the public' (LDNPA, 2018a). Each national park is administered by its own independent authority (NPA), funded by central government. An additional duty of each NPA is 'to seek to foster the economic and social well-being of local communities within the national park'

(LDNPA, 2018a). Unlike national parks in other countries where notions of wilderness and its preservation are paramount, in England the fact that national parks comprise of rural (agro-pastoral) and industrial uses, inhabited settlements and infrastructure alongside areas of ecological value means they are best defined as scenic 'cultural landscapes'.2

When considering how to govern such complex systems, Selman (2012) highlights the multiple fields of knowledge involved, including land use planning, heritage, ecology and economics. In practice, integrating these multiple fields of

\footnotetext{
${ }^{2}$ The International Union for Conservation of Nature (IUCN) classifies English national parks as protected area management 'Category V: Protected Landscape / Seascape', as distinct from 'Category II: National Parks' (Dudley, cited in Tatum, et al, p 168.)
} 
knowledge is challenging, as values are often in conflict, and management strategies encompassing them are not always reconcilable (Carr, et al, 2013). A tension between the 'multiple mandates' (Gross et al, 2009) of landscape protection and enjoyment, epitomised by environmental conservation on one hand and tourism and business interests on the other, has always been part of the national park idea. As such, the history of spatial planning in UK national parks is 'largely concerned with negotiating multiple landscape values through placemaking and conflict management' (Butler, cited in Tatum et al, 2017, p 168). As the organisations responsible for fulfilling the statutory purposes and duties of parks, NPAs are at the centre of contested decisions over land use and development. NPAs are required to develop management plans which are monitored and reviewed every several years. This responsibility is complicated by the fact that over $75 \%$ of UK national park space is privately owned, either by individuals, business, forestry or utilities (Sharpley, 2009, p 155). It is further complicated by the overlap with multiple local and regional council jurisdictions, meaning a NPAs role is to regulate development of land which is also subject to local planning regulation, not to mention other national and international conservation acts and heritage listings.

Given this challenging role, it is unsurprising that NPAs have been subject to criticism, typically regarding whether their planning policies are too restrictive (as perceived by socio-economic interests) or not restrictive enough (as perceived by conservation interests). NPAs have been critiqued for enforcing strict planning controls to the extent that parks are "preserved "in aspic" rather than evolving to reflect changing human / nature interactions' (Thompson et al, 2014:762). Conversely, conservationists decry the preservation of arguably unsustainable agro-pastoral and forestry practices in national parks as 'a betrayal of nature' (Monbiot, 2017; Thompson, 2010: 297 - 301). Research has highlighted that NPAs have lacked a holistic approach to planning and 
implementation, where pressures of day-to-day management mean 'strategic vision takes a back seat to control [planning and land use]' (Wearing et el, 2016, p 8; see also Land Use Consultants, 2001; DEFRA, cited in Sharpley and Pearce, 2007). It has been recommended that in rural areas valued for their scenic qualities, such as UK national parks, 'a joined-up approach between environment, development and education should be encouraged in order to facilitate sustainable future landscapes' (Park and Selman, 2009, p 200) rather than focussing exclusively on development controls.

In light of such criticisms, NPAs have sought to move beyond a narrowly defined conservation, and hence a restrictive planning role, to one that 'embrace[s] a wider set of objectives and a more collaborative approach to delivery' of park areas (Blackstock et al, cited in Dinnie et al, 2012, p 451). The peak body for NPAs in England's Policy Position Statement, Working in Partnership to Achieve National Park Purposes, affirms that:

National Park Management Plans are for the National Park, not just the National Park Authority. Common ownership is vitally important and NPAs put considerable effort in ensuring effective early engagement with partners in their preparation (National Parks England, 2008, p 3)

Looking beyond the national level, at an international level the UNESCO Convention Concerning the Protection of the World Cultural and Natural Heritage (known as the World Heritage Convention) established in 1972, set up the World Heritage List as a means of recognising that some places, both natural and cultural, are of sufficient importance to be the responsibility of the international community as a whole (DMCS, 2008: p. 7). The Convention specifies ten criteria by which a place may be judged to meet this level of importance, defined as 'Outstanding Universal Values' (OUV): 
Outstanding Universal Value means cultural and/or natural significance which is so exceptional as to transcend national boundaries and to be of common importance for present and future generations of all humanity (UNESCO, 2019, p. 19)

As well as defining what OUVs are, the Convention specifies that a property deemed to meet these criteria must have a management plan in place ensuring its conservation. Strategic plans are required to satisfy UNESCO that the protection, management, authenticity and integrity of properties are maintained, and that properties be maintained with the involvement - and to the benefit of - local communities:

Cultural landscape management and conservation processes bring people together in caring for their collective identity and heritage, and provide a shared local vision within a global context. Local communities need therefore to be involved in every aspect of the identification, planning and management of the areas (UNESCO, cited in Rossler, 2006, p 350)

In summary, in the UK cultural landscapes deemed to be of exceptional value are subject to national and international instruments, which set the highest levels of spatial planning protection. This can cause tensions between competing landscape interests, which has in turn seen a shift toward a more partnership based approach to strategic planning processes.

\section{Marketing, place branding and protected landscapes}

Just as effective planning is an integral part of national park and WHS management, it can be argued that communications - including marketing communication and branding - are also central to achieving effective management.

Historically, NPAs have had an uneasy relationship with marketing, despite the fact that commercialisation and tourism interests have accompanied national parks' establishment from the outset (Gross et al, 2009, p 277). Those in the parks sector have 
traditionally viewed marketing with suspicion and apprehensiveness (Wearing et al, 2016, p 10; Sharpley, 2007, p 562). In their 2007 study of English national parks, Sharpley and Pearce concluded that NPAs in England have a piecemeal and sometimes under informed approach to marketing. They recommended that NPAs should 'adopt a marketing-focussed strategic approach', asserting that

This would encourage, through research with partners, the identification of specific developmental and management needs, the establishment of appropriate communication and information channels for visitors, the local tourism industry, local communities and other stakeholders, and the basis for an integrated, planned approach to sustainable tourism development (Sharpley \& Pearce, 2007, p 571)

Since Sharpley and Pearce's 2007 study, NPAs have acknowledged the importance of engaging with sustainable tourism initiatives, though not necessarily engaging in marketing or branding per se. The National Parks England Policy Position Statement on Sustainable Tourism explains the role that tourism, and tourism marketing, plays in relation to national park purposes:

Promotion of sustainable tourism is not itself a specific purpose or duty of National Park Authorities, however, sustainable tourism contributes to National Parks' two statutory purposes [...] National Park Authorities seek to influence tourism and visitor management by working with partners to support and enhance the provision of information and the activities offered in National Parks. (2013, p 3)

At the international level, the development of the WH list has been associated with marketing and branding. WH inscription is intended to ensure the conservation of valuable sites, but there is also a recognition that it can 'act as the focus for education, 
tourism and economic regeneration' (English Heritage, cited in Norman, 2011. p 72). WHS designation 'has emerged as a highly valued brand used by countries in their efforts to market themselves as tourist destinations', a trend evidenced by the 'dramatic growth' in sites applying to UNESCO for WHS inscription (Ryan \& Silvanto, 2014: $327)$.

Although the term "brand" is now used in relation to $\mathrm{WH}$, it has been noted that there is no consensus on whether WH is a recognized brand per se (Adie et al, 2018, p. 400), or whether it is effective at increasing tourism revenue. Those who frame $\mathrm{WH}$ as a brand assert that it 'signals to the public' that a place is of international quality and value (King and Halfpenny, 2014, p. 768). Ryan \& Silvanto (2014, p. 329) observe it is a 'common assumption' that WHS designations are mainly sought to promote international tourism, while Aide et al (2018, p. 401) liken WHS to the branding of a tourism attraction or destination.

An increasing number of studies have sought to measure the economic effect of WH inscription, with the focus being on increased or differentiated (i.e. higher end) tourism activity. According to Aide et al (2018, p. 401) there are vastly 'conflicting results found within the WH marketing literature' regarding whether WH listing has a demonstrable effect on consumer awareness (i.e. brand recognition) or visitation. The potential for the $\mathrm{WH}$ brand to be effective may depend on existing consumer awareness, with studies questioning whether places that are already well known prior to becoming WHSs stand to gain from the "further "branding"" that WH status may bring (Norman, 2011, p. 76). At their extreme, sites who invest in WH nomination, and the subsequent management and marketing activities associated with it, may be 'placebo brands' or little more than 'franchisees' with negligible economic return (Aide et al, 2018; Aide 
2017).

In summary, to date there has been an uneasy relationship between national park planning and branding in the UK. There have been calls for better integration of planning and branding as management tools, as well as resistance to marketing-led approaches. On a global scale, WH listing, by comparison, has been perceived as a 'coveted brand and seal of approval' (Ryan \& Silvanto, 2014, p. 328), with some management organisations embracing WH status to further their place image in the marketplace. Evidence confirming the efficacy of $\mathrm{WH}$ as a recognisable destination brand, however, is limited.

\section{The Lake District case study}

\section{Methodology}

The following descriptive case study is focussed on the spatial planning and branding activities associated with WHS inscription in the English Lake District. The case study method is suited to exploring this proposition, given the intention to investigate 'a contemporary phenomenon' (spatial planning and place branding processes) 'within its real-life context' (a specific cultural landscape) 'when the boundaries between the phenomenon and context are not clearly evident' (Yin, 2003:13). Descriptive case studies in particular 'seek to reveal patterns and connections, in relation to theoretical constructs, in order to advance theory development' (Tobin, 2012: 289). In this study, the theoretical proposition that place branding can function 'as an instrument of strategic spatial planning' for regions (Oliviera and Ashworth, 2017: 31) is tested by describing how the work of the Lake District National Park Authority (LDNPA) - the 
governing body responsible for the governance of the Lake District National Park performs its spatial planning role, and how this relates to place branding processes. More specifically, the study traces how the LDNPA conceptualised, communicated and managed landscape identity in the period leading up to and immediately after the English Lake District's successful nomination for WHS status in July 2017. This case study limits its scope to focus on strategic planning and branding processes themselves, identifying how these align, influence and reinforce each other, or otherwise, within contemporary regional landscape governance. It does not seek to evaluate the success of the LDNPA spatial planning or branding per se.

Findings are based on the thematic analysis of qualitative primary data collected between April 2018 - May 2019. This data included planning and branding related documents produced by the LDNPA and its Partners; meeting minutes, reports, management plans, policy documents, brand guides / toolkits and associated branding material such as website content and media releases. Semi-structured interviews with senior personnel involved in the planning and branding of the Lake District were conducted:

- LDNPA Director of Sustainable Development Steve Ratcliffe

- LDNPA Head of commercial operations and communications Tonty Watson

- World Heritage Site Programme Manager for the National Trust Alex McCoskrie

- Creative Director of Cactus Creative Matthew Richardson

- Cumbria Tourism representative on LDNPP (and Elected Member of Cumbria Tourism Board of Directors), Haydn Spedding

The case study is structured in four parts. First, a brief description of the Lake District presents necessary geographical and historical context. Second, the approach to planning and branding adopted by the LDNPA before 2006 is summarised. Third, the work of the LDNPA between 2006 - 2016 is described, which corresponds with its 
establishment of the Lake District National Park Partnership, the group who led the successful English Lake District WHS nomination process. Part four focuses on planning and branding activities undertaken by the LDNPA in the immediate post-WHS inscription period.

\section{A brief history of the Lake District landscape}

The Lake District national park, located in the north-west of England in Cumbria, can claim several superlative 'ests'; it is England's largest national park $\left(2,292 \mathrm{~km}^{2}\right)$, it is home to England's deepest and largest lakes and its tallest mountain, and it contains the largest concentration $\left(645 \mathrm{~km}^{2}\right)$ of UK common land (LDNPP, 2015, p 14). Its topography is the result of glaciation over millennia, forming a dramatic landscape of steep mountains and distinctive narrow valleys (figure 1)

[insert Figure 1 near here]

The Lake District has a multifaceted history and identity; a cultural landscape whose form and image reflects the interaction of humans and nature since pre-historic times. It is shaped by generations of agro-pastoral and industrial traditions - sheep farming, mining, forestry- that evolved under the influence of the physical constraints of its mountain setting and in turn transformed that setting. The unique 'harmonious beauty' (LDNPP, 2015) that has evolved as a consequence of such human- nature interaction has inspired globally significant artistic and conservation movements. In the $18^{\text {th }}$ century, Romantic and Picturesque aesthetics flourished here, with the landscape ideas expressed in this milieu being credited with giving rise to the conservation movement. The National Trust, and subsequently the very origin of the concept of legally-protected 
landscapes - including national parks - has been traced to the artistic conventions and landscape values originating at that time.

The Lake District was confirmed as a national park in 1951 following decades of passionate lobbying by conservationist and interest groups. Conflicts over land use and values were evident from the outset, however, with local residents and farmers expressing concerns over the external bureaucratic controls and restrictions - that is to say changes to spatial planning - that park status could bring (Thompson, 2010, p. 301 - 303). The Lake District National Park Authority (LDNPA) was formed soon after as the Parks governing body.

As of 2015, the Lake District was home to a permanent population of 41,000 living in towns, villages and rural properties. It hosted an estimated 15.5 million visitors annually, an indicator of its longstanding status as a tourist destination and key industry for the area (LDNPP, 2015: 15, Sharpley, 2009: 157 - 160). Tourism is an important area of Cumbria's regional economy, and of this nearly half of tourism revenue for the region is generated within the Lake District (Cumbria Tourism, c. 2014, p. 9). The district includes 42,026 ha of Sites of Special Scientific Interest (SSSIs), over 10,000 ha of ancient semi-natural woodland, 16,500 archaeological sites and 1771 listed buildings. In short, the LDNP is a multi-layered cultural landscape of exceptional beauty, ecological value and heritage which simultaneously bears 'the hallmarks of modern developments [and] tourism infrastructure' (Sharpley, 2009, p 161).

\section{Pre-2006: LDNPA as a planning body}

In exercising its statutory role to conserve, enhance and promote enjoyment of the Lake District National Park, the LDNPA had, until recent years, functioned 
primarily as a planning body without any broader strategic function. According to Steve Ratcliffe, current LDNPA Director of Sustainable Development, when he commenced the role in 2004 there was:

significant turmoil for the LDNPA [...] because we saw ourselves primarily as the planning authority with very little cognizance of any other role we might have. We weren't necessarily liked by many, and certainly we weren't in partnership discussions with any (Ratcliffe, personal communication, April 2018).

This lack of strategic leadership by the LDNPA negatively affected the image of the LDNPA and any collaborative place promotion attempts it made. In 2004 the LDNPA underwent a performance assessment with assistance from the 'Improvement and Development Agency' which marked the LDNPA's external relations as 'poor' (see also Sharpley \& Pearce, 207, p 561). This directly affected its relationship with tourism and marketing of the region: For example, Ratcliffe (personal communication, April 2018) characterises the relationship between the LDNPA and local destination marketing organisation Cumbria Tourism (formerly Cumbria Tourism Board) as dysfunctional, recalling how the former communicated with the latter 'through the Westland Gazette' [the local newspaper...] we would do an article on a Friday and the following Friday we could expect a response...'

The schism between the LDNPA and commercial / tourism sector interests in the region were clearly reflected in their respective stances vis a vis potential World Heritage listing. In 2004 the LDNPA sought feedback from potential partners about submitting a WH nomination to UNESCO in the newly created 'cultural landscapes' category. This was met with concerns about associated planning restrictions and their negative impact on commercial and tourism interests. In an investigation conducted by Cumbria County 
Council on whether to support a WHS bid or not, Cumbria Tourism expressed 'serious reservations about the value of WHS for Cumbria', stating:

WHS status is likely to have a dampening effect on the economy, regeneration, housing, investment and tourism since this is primarily a preservation/conservation measure. WHS would be a material consideration in the assessment of planning applications [...] In a climate of limited public funding resources there are more urgent needs to address to assist improvement of the visitor experience in the Lake District (CCC, 2005, p. 13)

In summary, prior to 2006 the Lake District was managed by the LDNPA from a narrow planning perspective, without direct engagement or alignment with regional the destination marketing organisation, and it did not have support for pursuing WHS status from tourism stakeholders.

2006 - 2016: The Lake District National Park Partnership and WHS

\section{nomination}

In 2004 the LDNPA began a process that resulted in the establishment of the Lake District National Park Partnership ('the Partnership'). The 'poor' performance assessment cleared the way for discussions with the organisations, including Cumbria Tourism, who would go on to be members of the Partnership, a group based on a 'collective commitment to work together in the best interest of the National Park, its environment, communities, economy and visitors' (LDNPA, 2015). The process of gaining trust and a shared commitment to working together happened incrementally, with the Partnership being formalised in 2006. 
The Partnership ‘brought together a very disparate group' of stakeholders (Spedding, 2019, personal communication) including organisations from the public, private, community and voluntary sectors. The Partnership membership and organisational structure, including sub-groups to address specific issues, is summarised at figure 2.

[insert Figure 2 near here]

The interests represented within the Partnership, from tourism and forestry to environmental conservation and heritage protection, necessitate careful governance and ways of working to be effective. The LDNPA note that such a complex partnership can only work though ongoing communication and 'healthy conflict':

[There are] compromises throughout [but] you achieve things through compromise over the long term as this builds trust [... the] Partnership enables us to have those very authentic conversations and allows us to disagree but in a positive way, stay together and try to work through those disagreements [...] the rest of the world sees a Partnership that is remarkably intact and very strong, but below that lies intensive negotiations virtually on a daily basis. [We] constantly bang heads together [to find solutions...] it's slow, it's painful, but it's working (Ratcliffe, personal communication, April 2018)

Cumbria Tourism's representative on the Partnership since its formation, Haydn Spedding, echoes this assessment, stating

it has worked very very well [...as a] forum to debate the way forward [...] the success of the Partnership is that everybody gets together in one room and can debate what's proposed and what's happening, and the problems can be seen from two sides rather than just one - from twenty different sides [...] You can't expect to 
get your own way on everything, that's not how it works. You have to be in a forum where other people understand what you need and you understand them (Spedding, personal communication, May 2019)

The early task of the Partnership was to develop and commit to a strategic vision for the Lake District, which was agreed in March 2006 as:

\section{An inspirational example of sustainable development in action.}

A place where its prosperous economy, world class visitor experiences and vibrant communities come together to sustain the spectacular landscape, its wildlife and cultural heritage. Local people, visitors, and the many organisations working in the Lake District or have a contribution to make to it, must be united in achieving this (LDNPA, 2006)

This Vision statement addresses conservation and the economy within the context of a valued landscape whose ongoing viability depends on sustainable development and cooperation. It was the first time that a UK national park had articulated 'prosperous economy' and 'world class visitor experience' in a park vision; given the statutory duty to conserve and enhance the park, it was at that time 'an anathema' to put these commercial imperatives up front (Ratcliffe, personal communication, April 2018). It also took the aims and remit of the LDNPA beyond those of being a traditional planning organisation to a more strategic leadership role.

A key activity of the Partnership in working toward this Vision was its development of the English Lake District WHS nomination bid. It is important to note the economic context that motivated the LDNPA, and the Partnership, to join together to undertake the lengthy process of developing a nomination bid. Like national park designation, the primary purpose of World Heritage inscription was to conserve globally important natural or cultural heritage (Rebanks Consulting, 2013, p 7), however World Heritage 
status was also intentionally sought as a means of improving economic sustainability in the Cumbria region. In December 2005 the LDNPA published a report 'Towards World Heritage' which aimed to 'summarise the debate so far and describe the potential benefits, opportunities and value of achieving World Heritage Site inscription' (LDNPA, 2005, p. 2). This report concluded that WHS 'could be used as a tool to attract new visitors, new investment and a new sense of purpose to The Lake District National Park. It is a means of bringing partners together to re-energise the park's image, its tourism offer and its economic development' (LDNPA, 2005, p. 7). Reassurances that WHS listing would not necessarily curtail development or add extra planning controls were included (LDNPA, 2005, p. 7). Subsequent reports commissioned by LDNPP members cited existing studies and produced further original evidence asserting that becoming a World Heritage brand can bring economic benefits but only 'by desiring a socio-economic benefit' and purposefully leveraging the World Heritage brand for this purpose (Rebanks Consulting and Trends Business Research Ltd, 2009; Rebanks Consulting, 2013 p 7) (see figure 3)

[insert Figure 3 near here]

Rebanks' description of World Heritage inscription echoes descriptions of strategic visioning which are found in place branding:

for a significant minority of sites becoming a World Heritage Site creates a situation whereby the local stakeholders collectively ask themselves the critical question, 'Why is our place unique, special and globally important?' [...] as a result of answering that question [they] found themselves at the cutting edge of a movement around the world which seeks to focus the economic development of places on their uniqueness, their authenticity, their distinct sense of place, and the 
depth of their identity and culture (Rebanks Consulting and Trends Business Research Ltd, 2009, p 4)

Following years of preparatory work, the Partnership's 2016 World Heritage Nomination, a detailed dossier of four volumes of material several hundred pages long, was completed. The centrepiece of the dossier was the Partnership's Plan: The Management Plan For The English Lake District 2015-2020 ('The Plan') which was adopted in December 2015 (LDNPP, 2015).

The Plan represents a change in the strategic planning of the national park as it merged National Park purposes and World Heritage values into a single comprehensive planning document. According to Cumbria Tourism, this approach "came out the debate quite strongly amongst the commercial side of the Partnership' (Spedding, 2019, personal communication)

\footnotetext{
We had to look at the practicalities, as a Partnership, of how inscription as a WHS would affect us. Cumbria Tourism always said that we didn't want to see an extra layer of governance. We already had Local Authorities, we already had a National Park, and we didn't want a WH Management Plan on top of the National Park [...] We didn't want to see a different set of rules. [LDNPA] in its wisdom took this on board (Spedding, 2019, personal communication)
}

The Plan sought to address long-term challenges faced by the park including threats faced by climate change, development pressures, changing agricultural practices and tourism (UNESCO, 2017). It addressed World Heritage criteria by first articulating the Lake District's Outstanding Universal Values (OUVs) overall, and then in detail on a 
valley-by-by valley basis, before putting forward the Partnership's Vision and an integrated plan of strategies, actions and targets designed to realise that vision so as to manage the sites' OUVs (figure 4).

[insert Figure 4 near here]

A central tenet of the statement of OUV, and a theme which runs throughout the Plan, is that the Lake District is an 'evolving' dynamic cultural landscape:

The Lake District's spectacular landscape, its wildlife and cultural heritage can only possibly be sustained and protected if the living working places that have created it - and continue to evolve it - are able to thrive (LDNPP, 2015, preface, emphasis added)

In 2017 it was this version of the Lake District, and the corresponding world heritage criteria for cultural landscape OUVs, that were inscribed on the World Heritage List (see table 1)

[insert table 1 near here]

This research identified three main ways in which world heritage inscription implicates spatial planning practice in the Lake District; first, the way the definition of an evolving landscape is interpreted in strategic planning terms; second, the way the LDNPA works internally, and finally the way it works in partnership.

First, the Partnership Plan which formed part of the Lake District's nomination for World Heritage is also the statutory plan for managing the National Park. Consequently, the definition of OUVs, and the strategic policy, planning 
decisions and actions of the LDNPA, are informed by this definition. According to the Head of commercial operations and communications at the LDNPA, being inscribed as an ever-changing cultural landscape 'creates a mandate for us as a national park to be that evolving place [...the inscription] washes away the aspic we've been preserved in and encourages development (Watson, personal communication, April 2018). The LDNPP summarize this position on their website:

\section{The living, working cultural landscape of the Lake District means change is both inevitable and essential. The Lake District has evolved for centuries and it will continue to do so. The management plan is focused on ensuring that change is managed in such a way that it will not harm the attributes of Outstanding Universal Value or our special qualities so that World Heritage status becomes a driver for positive change $[\ldots]$ change needs to be balanced}

(LDNPP, 2018c, emphasis in original)

It should be noted that the existing planning controls which the LDNPA exists to enact represent the highest level of protection in UK planning law, and these have not changed. Nevertheless, emphasising that the existing cultural landscape is a product of human adaptation and change introduces a strong narrative into any debates and interpretations of policy amid competing calls for development and / or conservation.

Second, the way in which the Plan sought to move beyond planning issues to embrace place management more holistically, including branding, is reflected in the organisational structure within the Authority at a senior level which supported its development and implementation (figure 5).

[insert Figure 5 near here] 
Ashworth \& Kavaratzis (2018, p 435) note public administrations should have the necessary internal organisation and ensure any place branding efforts are 'not isolated as a series of disembodied logos, design features and straplines which divorces product promotion from product creation and management'. The LDNPA's organisational structure does this by ensuring personnel involved in 'product promotion' (communicating landscape values and the world heritage brand) are in communications with, and sit on Partnership sub-groups with, people in commercial operations and planning ${ }^{3}$ ('product creation and management').

Third, the implementation of the Plan by the Partnership as a whole means that the Authority is bound by its own management plan to work in close collaboration with its stakeholders, and stakeholders are in turn accountable for some of the actions outlined in the Plan. In practical terms this does not eliminate the tensions that accompany planning policy and decisions in national parks, since 'progress is conflict, planning is conflict [and] every decision is conflict' (Ratcliffe, personal communication April 2018). Strong differences of opinion over sustainable tourism development, agricultural / land management policies and planning decisions will continue as they have done previously; however, the Partnership forum allows members to engage in productive debates, at times agreeing to disagree on individual decisions but having a long term strategic alliance and common goals, be these related to planning or marketing / branding decisions.

In summary, a process of partnership building underpinned the strategic visioning and detailed Management Plan for the Lake District as a WHS. This process sought to

\footnotetext{
${ }^{3}$ In some cases are the same person performs multiple roles, for example being LDNPA head of communications and head of commercial operations.
} 
incorporate a range of place values and stakeholder interests. The perceived benefits of the WH brand were a key motivating factor for undertaking this work. The result was successful WHS inscription, described by the LDNPA head of communications as the 'biggest achievement' of the Partnership to date.

\section{7 onwards - the English Lake District WHS as a place brand}

We have already seen that a factor motivating the Partnership to nominate the national park as a world heritage site was the potential leverage this would provide by becoming part of the world heritage 'brand'. This section provides a description of the brand, discusseshow it was developed following inscription in July 2017, and presents evidence of post-WHS inscription planning and brand implementation activities.

Following pre-inscription and immediate post-inscription marketing campaigns ${ }^{4}$, the Partnership's World Heritage Marketing sub-group led the development of a long-term official place brand for the English Lake District World Heritage Site. The brand was completed in July 2018 and officially launched at the Westmoreland County Show in September 2018 (figure 6), thus reinforcing the connection between WHS status and the local provenance of agricultural goods produced in this cultural landscape. The main

\footnotetext{
${ }^{4}$ Leading up to the 2017 inscription, the Partnership undertook external communications campaigns to garner support. A campaign \#We Are the Lakes' publicized the nomination itself, and following the July 2017 inscription several publicity and PR campaigns ensued, such as a Royal Mail stamp and a launch event attended by royalty, politicians and over 100 local organisations.
} 
brand output takes the form of a website http://lakesworldheritage.co.uk/. As well as featuring local stories and interactive \# social media campaigns, the site provides fully accessible links to the brand toolkit which explains the brand expression (a 37 page brand guideline document) and provides branding collateral for stakeholders - be they Partnership members or any organisation in the Lake District - to download and use (LDNPP, 2018c).

The brand guide contains conventional place brand content; a wordmark (a text-only logo), fonts, a graphic design colour palette for branding collateral, photography, and examples of these elements being used in combination. A summary of key information about the World Heritage inscription for those wishing to understand the underlying 'World Heritage Story' completes the guide, including what UNESCO and the world heritage convention is, why the Lake District is a world heritage site, what its OUVs are, and summarising the benefits of inscription / branding for stakeholders (LDNPP, 2018c).

The main component of the brand expression, the wordmark (figure 7), spells out the full UNESCO inscription title, accompanied by a 'verb' that can be chosen for a variety of 'sector messages'.

[insert Figure 7 near here]

The simplicity and flexibility of the wordmark has been designed to encourage stakeholders to customise itwith their 'sector messaging'. There are currently 32 verb 
variations ${ }^{5}$ which the guide divides into 8 sector categories: tourism, farming, food and drink, residents and local government, travel and transport, manufacturing, education, and conservation (LDNPP, 2018, pp. 20 - 28). Designer Matthew Richardson (personal communication 2018) remarks that this adaptability was well received by partners because each could 'totally see how that could work for me', feedback echoed by the National trust who are 'delighted it is so flexible' (McCoskrie, personal communication, 2018.)

The brand identity is based on the World Heritage inscription and the place identity it articulates, directly responding to the strategic vision and OUVs that the Partnership developed over a long period. Whereas other place branding processes may commence with the identification and articulation of a brand's vision, personality, USP, and so on ( Porter, 2016, pp. 77 - 82), in this case the foundations for the place brand identity and the key stakeholders to take ownership of it were already in place. By being a flexible wordmark, not a reductive logo, the brand expression respects the working relationships of a partnership, which relies on different landscape values / interests being represented.

Brand development itself was co-ordinated by the Partnership's world heritage marketing subgroup (see figure 2) working with Cactus Creative, a well-established Cumbria-based agency who have previously worked with Cumbria Tourism to develop place brand material for neighbouring areas in the Cumbria region. Designs emerged following process of consultation with Lake District organisations . Given the range of place identities and interests involved, this meant not privileging one theme, sectoror

\footnotetext{
${ }^{5}$ The Lake District Partnership accepts suggestions for additional words from stakeholders..
} 
image over another.. The sentiment expressed by Cumbria Tourism reflects a pragmatic attitude toward achieving a workable umbrella brand identity, asserting that 'as long as you've got something that's OK, that's the most important thing, everyone will want something slightly different [but] we all get behind it (Spedding, 2019, personal communication.)

Brand uptake is not being quantified, however initial usage suggests a range of sectors from transport, farming and tourism are using the brand (McCoskrie, personal communication, 2019.) Cumbria tourism 'encourage all members to use the branding' (Spedding, 2019, personal communication).It conducted research one year after WHS inscription which reported that two thirds of [tourism] businesses think WHS status will have a positive impact on their business, and over half already plan to use the WHS status to attract visitors (LDNPP, 2018d). The enthusiasm for the WH brand and its alignment with the strategic management of the Lake District overall as far as Cumbria Tourism is concerned was summarised by Spedding 'The management of the LDNP compared to fifteen years ago is completely different. I was one of the most bitter critics of the LDNPA but now I'm one of its most vociferous supporters' (personal communication, 2019).

Beyond the tourism sector, an example where WHS brand communications and strategic planning objectives have overlapped in practice is that of sustainable public transport: Stagecoach Buses, the local public transport provider for the Lake District, use WHSbrand collateral in their 2019 literature. Stagecoach also provided an open top 
bus for free trips on World Heritage Day on April 18, 2019 (figure 8), and are developing a 'Driver WH Ambassador' scheme to further promote WH values while also promoting greater uptake of sustainable transport options (McCoskrie, personal communication, 2019.)

[insert figure 8 near here]

It is important to recall that the Management Plan for the area focuses on sustaining the OUVs of the landscape, and that this is based on the ongoing implementation of the strategies within that management plan - which include planning strategies and targets associated with sustainable land use, transport and so on. Formal processes of reporting progress on this implementation are ongoing, with the next State of the Park report due in 2019.

\section{Discussion}

This case study illustrated how the Lake District is a cultural landscape whose identity is the result of a mix of historic and persistent land uses and values, including agropastoral, industrial, touristic, artistic, and environmental. National park designation over 60 years ago led to high levels of landscape protection, with the LDNPA being responsible for managing competing park purposes, primarily through planning policies and controls. In recognition of the need for co-operation with external organisations and the wider public to exercise its role more effectively, the LDNPA evolved a Partnership model (LDNPP), which over time secured buy-in from a diverse mix of stakeholders. 
Within this context, the decade-long work of the Partnership toward successful World Heritage inscription has served as a process of landscape visioning, management and promotion rolled into one. Documents produced by the Partnership show that the collective decision to pursue WHS, with the cost, time and obligations this process entailed, was motivated by the perceived multiple benefits that could ensue, including brand recognition.

By agreeing on a shared vision of what the landscape is and should become, the Partnership deliberately created a basis for subsequent strategic planning and WHS branding. This vision was able to unite different interests and give validity to different place identities including the 'spectacular landscape' of conservation, the 'living working landscape' of farming and the 'sustainable development' of tourism. Then, by developing an extensive management plan which defined the landscape in terms of Outstanding Universal Values i.e. in accordance with World Heritage criteria, the Partnership sought to spell out how that vision would be achieved, whilst securing World Heritage brand status, and its potential economic benefits, in the process.

Of relevance to strategic planning and place branding processes alike is is the definition of an evolving cultural landscape, a notion that accommmodates multiple stakeholders whose reasons for valuing the Lake District landscape are varied. Securing agreement from diverse partners to adopt the Plan -endorsing the place identity it describes and the actions it proposes to undertake to conserve that identity - could only occur if it offered the potential for mutual and collective benefit. For the LDNPA, this meant operating as 'a business, a planning authority, and a facilitator' of stakeholder relationships (Ratcliffe, personal communication, April 2018). It also meant emphasising that the cultural landscape of the Lake District is an 'evolving 
masterpiece', thus simultaneously asserting the need to protect the existing landscape (masterpiece) while also being open to change (evolution, including physical landscape change in planning). It necessitated co-developing a brand identity that reflected this diversity, according with previous research which has shown that 'region brands have the capability of providing something for everybody, when they are created by everybody' (Oliveira, 2016, p 54).

The Lake District example, therefore, conforms to the theoretical proposition that the strategic planning of regional-scale landscapes can be aligned with place branding through a very deliberate governance and decision-making process. The Lake District case suggests that developing a shared strategic vision for the landscape can set the foundation for various governance processes, including planning and branding decisions. In short, a comprehensive understanding of a cultural landscape's values (place identity) was articulated, then spatially and socio-economically managed (planned), and then communicated through a complementary branding process, with stakeholder collaboration throughout.

The alignment of strategic planning and branding can be traced through the $\mathrm{WH}$ nomination and communication process across various stages, as illustrated in figure 9.

[insert Figure 9 near here]

An additional characteristic of this case, which sheds new light on conceptualisations of WHS as a 'brand', is that WHS can be seen to function as a place branding process rather than merely a destination or tourism branding one. Just as strategic planning takes a long term and holistic approach to spatial governance, so too 
does place branding take a more holistic and longer term approach than tourism / destination marketing alone. Tourism is but one sector represented within the LDNPP, and the WH brand represents the Lake District as more than just a tourist destination. The way in which WH can be seen as a framework aligning strategic spatial planning and place branding in this manner is illustrated in figure 11.

[insert Figure 11 near here]

Further case studies of cultural landscape management elsewhere are needed to compare with the English Lake District example, which is exceptional insofar as it has merged National Park governance and WH planning and place branding into a single process. While 'the allure of the World Heritage prize' and the brand benefits it is assumed to bring can sufficiently motivate stakeholders to work together in this manner (Norman, 2011, p. 76), it would be interesting to see if the strategic planning of cultural landscapes of less than 'outstanding universal value' could nevertheless benefit from a similar visioning + planning + branding process. The combination of strategic planning and place branding suggested above could, in theory, be applied to protected landscapes elsewhere, albeit the notion of an 'evolving landscape' identity, and its interpretation in planning policies and brand design are unique to the Lake District. Regardless of the particular qualities of place being managed, this example highlights how managers of contested landscapes require time and human resources to develop collaborative ways of working which fit their specific historical-social-economicenvironmental context. A characteristic shared by spatial planning and place branding is the necessity of collaboration and partnerships between the public sector and a range of 
stakeholders; the ability to align strategic plans, place brands and their ongoing implementation relies on this most of all.

\section{References:}

(note some references were amended in post-acceptance production and will differ from published version):

Aide. B., Hall, C. \& Prayag, G. (2018). World Heritage as a placebo brand: a comparative analysis of three sites and marketing implications. Journal of Sustainable Tourism, 26 (3): pp. $399-415$.

Aide, B. (2017). Franchising our heritage: The UNESCO World Heritage brand. Tourism Management Perspectives, 24: pp. 48 - 53.

Ashworth, G and Kavaratzis, M (2018). The Roles of Branding in Public Administration and Place Management: Possibilities and Pitfalls. In E. Ongaro, \& S.Van Thiel (Eds.) The Palgrave Handbook of Public Administration and Management in Europe (pp. 425 - 439). Palgrave Macmillan, UK.

CCC (Cumbria County Council), (2005). Overview and Scrutiny: Lake District Bid for World Heritage Site Status. September. Available at: http://councilportal.cumbria.gov.uk/Data/County\%20Council/20050915/Agenda/(item \%2012)\%20Appendix\%20Lake\%20District\%20Bid\%20for\%20World\%20Heritage\%20 Site\%20Status.pdf [accessed May 2019]. 
Dinnie, E., Blackstock, Kirsty, L. \& Dilley, R. (2012). Landscapes of Challenge and Change: Contested Views of the Cairngorms National Park. Landscape Research, 37(4), 451-466.

Gross, A.C., Poor, J., Sipos, Z. \& Solymossy, E. (2009).The multiple mandates of national park systems. Place Branding and Public Diplomacy. 5(4): 276-289.

ICOMOS, (2017). Evaluations of Nominations of Cultural and Mixed Properties ICOMOS report for the World Heritage Committee 41st ordinary session, Kracow, 2 12 July 2017http://whc.unesco.org/archive/2017/whc17-41com-inf8B1-en.pdf

Kavaratzis, M. (2005). Place branding: a review of trends and conceptual models. The Marketing Review, 5 (4): pp. 329 - 342.

King, L., \& Halfpenny, E. (2014). Communicating the World Heritage brand: visitor awareness of UNESCO's World Heritage symbol and the implications for sites, stakeholders and sustainable management. Journal of Sustainable Tourism, 22 (5): pp. $768-786$.

Land Use Consultants, (2001). Development Planning Control in National Parks in England and Wales. Scottish Executive: Edinburgh.

LDNPA, (2018a). History of the National Park. Available at: http://www.lakedistrict.gov.uk/aboutus/nat_parks_history 
LDNPA, (2018b). Partnership sub groups \& events. Available at:

http://www.lakedistrict.gov.uk/caringfor/lake-district-national-park-

partnership/partnership-subgroups

LDNPA, (2018c). World Heritage Site brand launched today at Westmorland County Show. 13 September 2018. Available at:

https://www.lakedistrict.gov.uk/aboutus/media-centre/latest-news/newsreleases/world-heritage-site-brand-launched-today-at-westmorland-countyshow [Accessed October 2019]

LDNPA (2005). Towards World Heritage. Lake District National Park Authority, Kendal UK.

Available online at: http://www.wbcoft.org.uk/world_heritage_status.htm [accessed April 2019].

LDNPP, (2018c). Brand toolkit. Available at:

http://lakesworldheritage.co.uk/toolkit/

LDNPP, (2018d). Lake District marks first year as World Heritage Site. Available at: http://www.lakedistrict.gov.uk/aboutus/media-centre/latest-news/newsreleases/lake-district-marks-first-year-as-world-heritage-site

LDNPP (2015). The Partnership's Plan: The Management Plan For The English Lake

District 2015-2020. Available at: http://www.lakedistrict.gov.uk/caringfor/lake-

district-national-park-partnership/ldnppmanagementplan .

LDNPP (2006). Our vision and values. Available at:

http://www.lakedistrict.gov.uk/aboutus/nationalparkvision 
Monbiot, G. (2017). The Lake District's world heritage site status is a betrayal of the living world. The Guardian. 11 July. Available at:

https://www.theguardian.com/commentisfree/2017/jul/11/lake-district-worldheritage-site-sheep

National Parks England (2013) Policy Position Statement - Sustainable Tourism [online]. Available at:

http://www.nationalparksengland.org.uk/_data/assets/pdf_file/0008/767474/NPEPosition-Statement-Sustainable-Tourism-2013.pdf

National Parks England (2008). Policy Position statement on working in partnership to deliver national park purposes. [online]. Available at: http://www.nationalparksengland.org.uk/_data/assets/pdf_file/0006/717855/ENPAAPosition-Statement-Working-in-Partnership-to-deliver-National-Park-Purposes.pdf English National Park Authorities Associations, London.

Norman, K. (2011). Should the UK be nominating More World Heritage Sites? Present Pasts, 3 (2): 72 - 79 .

Oliveira, E. and Ashworth, G.J. (2017) 'Place branding in Strategic Spatial Planning: Challenges and Opportunities' (Chapter 2), In: Adriana Campelo (Ed.), Handbook of Place Branding, Edward Elgar publishing: pp. 22-40.

Oliveira, E. (2016). Place branding as a strategic spatial planning instrument: A theoretical framework to branding regions with references to northern Portugal. Journal of Place Management and Development. 9 (1): 47-72. 
Park, J. J. and Selman, P. (2009). Attitudes Toward Rural Landscape Change in England. Environment and Behavior. 43 (2): 182 - 206.

Porter, N. (2016). Landscape and branding: The promotion and production of place. Oxford: Routledge.

Rebanks Consulting Ltd \& Trends Business Research Ltd (c. 2009). The Economic Gain: Research and Analysis of the Socio Economic Impact Potential of UNESCO World Heritage Site Status. Lake District World Heritage Project, Kendal, Cumbria. Available at:

http://icomos.fa.utl.pt/documentos/2009/WHSTheEconomicGainFinalReport.pdf Rebanks Consulting (2013). How the Lake District (and Cumbria) can benefit from World Heritage status (and a simple action plan to make it happen). Available at: http://www.lakedistrict.gov.uk/caringfor/partnership?a=385832

Rebanks, J. (2016). The Shepherd's life: a Tale of the Lake District. London: Penguin.

Ryan, J. \& Silvanto, S. (2014). A Study of the Key Strategic Drivers of the Use of the World Heritage Site Designation as a Destination Brand. Journal of Travel \& Tourism Marketing, 31 (3): pp. $327-343$.

Selman, P. (2012). Sustainable landscape planning: the reconnection agenda. London: Routledge. 
Sharpley, R. \& Pearce, T. (2007). Tourism, Marketing and Sustainable Development in the English National Parks: The Role of National Park Authorities. Journal of Sustainable Tourism. 15 (5), 557-573.

Sharpley, R. (2009). The English Lake District - national park or playground? In: W. Frost and C.M. Hall (Eds). Tourism and National Parks: International Perspectives on Development, Histories and Change. (pp. 155 - 166) Oxford: Routledge.

Tatum, K., Porter, N. and Hale, J. (2017). A feeling for what's best: Landscape aesthetics and notions of appropriate residential architecture in Dartmoor National Park, England Journal of Rural Studies. 56, 167-179.

Thompson, I (2010). The English Lakes; a history. Bloomsbury: London.

Thompson, N., Raley, M., Garrod, G. and Carroll, T. (2014). Planning in England's National Parks: Ensuring Quality Sustainable Development? Newcastle University: National Parks England.

Tobin, R. (2012). 'Descriptive Case Study'. In: Mills, A., Durepos, G. \& Wiebe, E. [Eds]. Encyclopedia of Case Study Research. SAGE publications, Thousand Oaks: pp. $289-292$.

UNESCO, (2017). Decision: 41 COM 8B.30 The English Lake District (United Kingdom of Great Britain and Northern Ireland). [online]. Available at: https://whc.unesco.org/en/decisions/6902 
UNESCO (2017). Operational Guidelines for the Implementation of the World Heritage

Convention. Available at: https://whc.unesco.org/en/guidelines/ [accessed May 2019].

Van Assche, K., Beunen, R. and Oliveira, E. (2019). Spatial planning and place branding: rethinking relations and synergies. European Spatial Planning.

Wearing, S., Scheinsberg, S. \& Tower, J. (2016). Marketing National Parks for

Sustainable Tourism. Channel View Publications; Bristol.

Yin, R. (2003). Case Study research: Design and Methods. $3^{\text {rd }}$ ed. Sage, Thousand Oaks California.

TABLES AND FIGURES: 


\begin{tabular}{|l|l|}
\hline $\begin{array}{l}\text { UNESCO World Heritage criteria } \\
\text { (OUVs) }\end{array}$ & $\begin{array}{l}\text { Corresponding English Lake } \\
\text { District OUVs }\end{array}$ \\
\hline $\begin{array}{l}\text { Criterion (ii) ... an important interchange of } \\
\text { human values over a considerable span of } \\
\text { time within a closely defined area. }\end{array}$ & $\begin{array}{l}\text { Identity - a landscape of exceptional } \\
\text { beauty, shaped by persistent and } \\
\text { distinctive agro-pastoral traditions } \\
\text { and local industry which give the }\end{array}$ \\
\hline $\begin{array}{l}\text { Criterion (v) ... an outstanding example of } \\
\text { a traditional human land-use which is } \\
\text { representative of a culture and human } \\
\text { interaction with the environment which is } \\
\text { vulnerable under the impact of irreversible } \\
\text { change. }\end{array}$ & $\begin{array}{l}\text { Lake District a special character } \\
\text { inspired artistic and literary } \\
\text { movements and generated ideas } \\
\text { about landscapes that have had } \\
\text { global influence and left their } \\
\text { physical mark }\end{array}$ \\
\hline $\begin{array}{l}\text { Criterion (vi) ... being directly or tangibly } \\
\text { associated with events or living traditions, } \\
\text { with ideas, or with beliefs, with artistic and } \\
\text { literary works of outstanding universal } \\
\text { significance. }\end{array}$ & $\begin{array}{l}\text { Conservation - it is a landscape } \\
\text { which has been the catalyst for key } \\
\text { developments in the national and } \\
\text { international protection of landscapes }\end{array}$ \\
\hline
\end{tabular}

Table 1. World Heritage Convention criteria and their application in the English Lake District. Sources: LDNPP, 2015; LDNPP, 2018c. 




Figure 1. Map of the English Lake District. World Heritage / National park site boundary (purple outline), individual valleys (orange) Source: LDNPP, 2015, p 33, p. 12. 


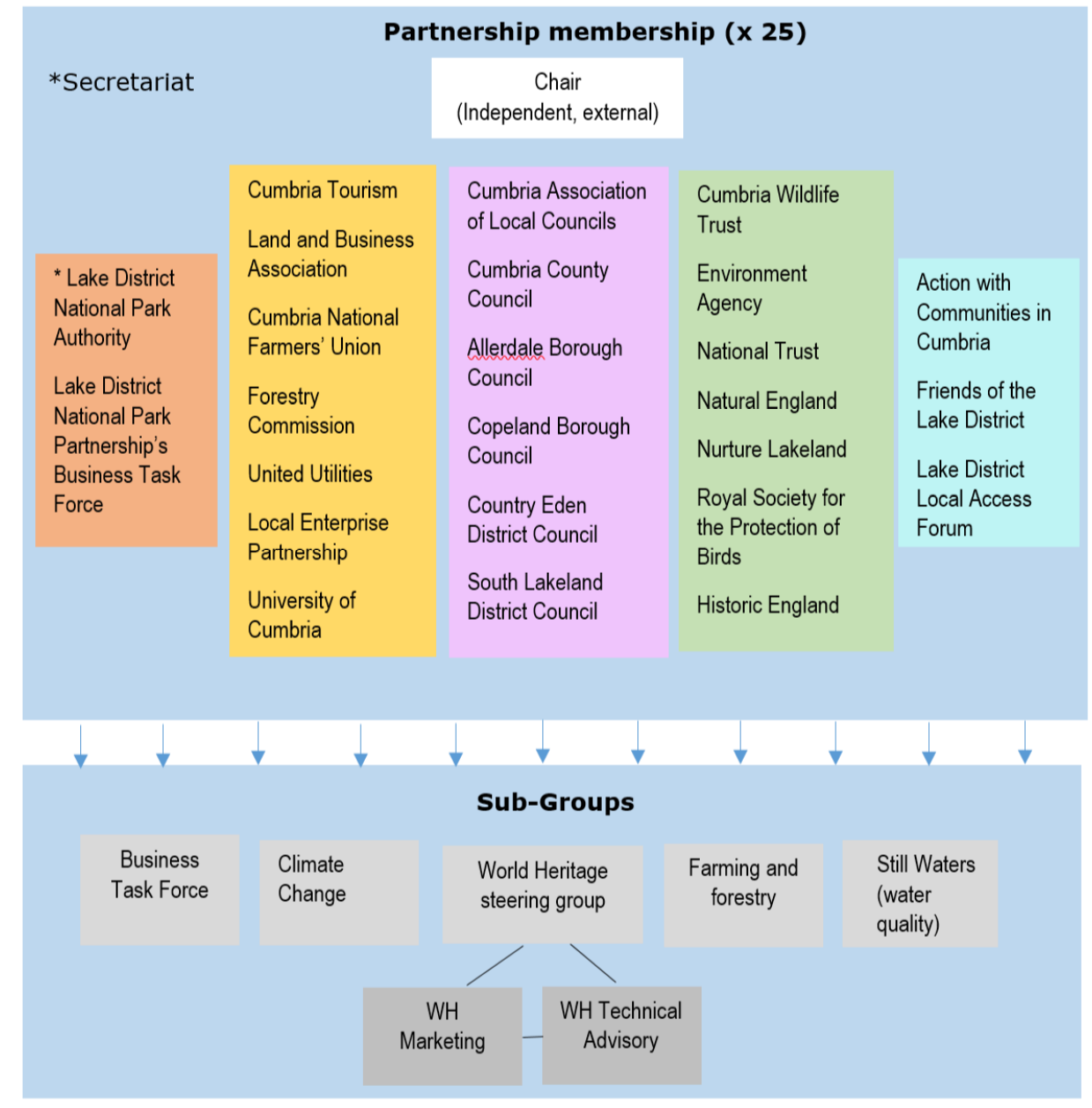

Figure 2. Lake District Partnership membership and structure as of 2018. Source: author. 


\section{'The Seven Potential Benefits from World Heritage +}

\section{for the Lake District (Cumbria)'}

1. Raising international profile and competitiveness

Global PR boost - uniting behind a vision of what is best about this place

endorsed by 190 countries

2. Upgrading the visitor economy

Cultural (WH) visitors, quality and storytelling

3. Focuses the efforts to sustain the 'underpinning' cultural landscape

Farming and culture sustained and ideally given contemporary resonance

4. Enhancing ability to secure funding / investment

WHS would raise the profile of LD with funders

5. Attracting and retaining talent

Civic and commercial pride in place focused on World-Class 'lifestyle offer' of destination

6. Creating entrepreneurial opportunities

Translating OUV into $£ £ £$

7. Being in the WHS elite club

Opportunities for global collaboration/ research

Figure 3. 'The Seven Potential Benefits from World Heritage + for the Lake District (Cumbria)'. Source: extract from Rebanks Consulting, 2013, p 2. 


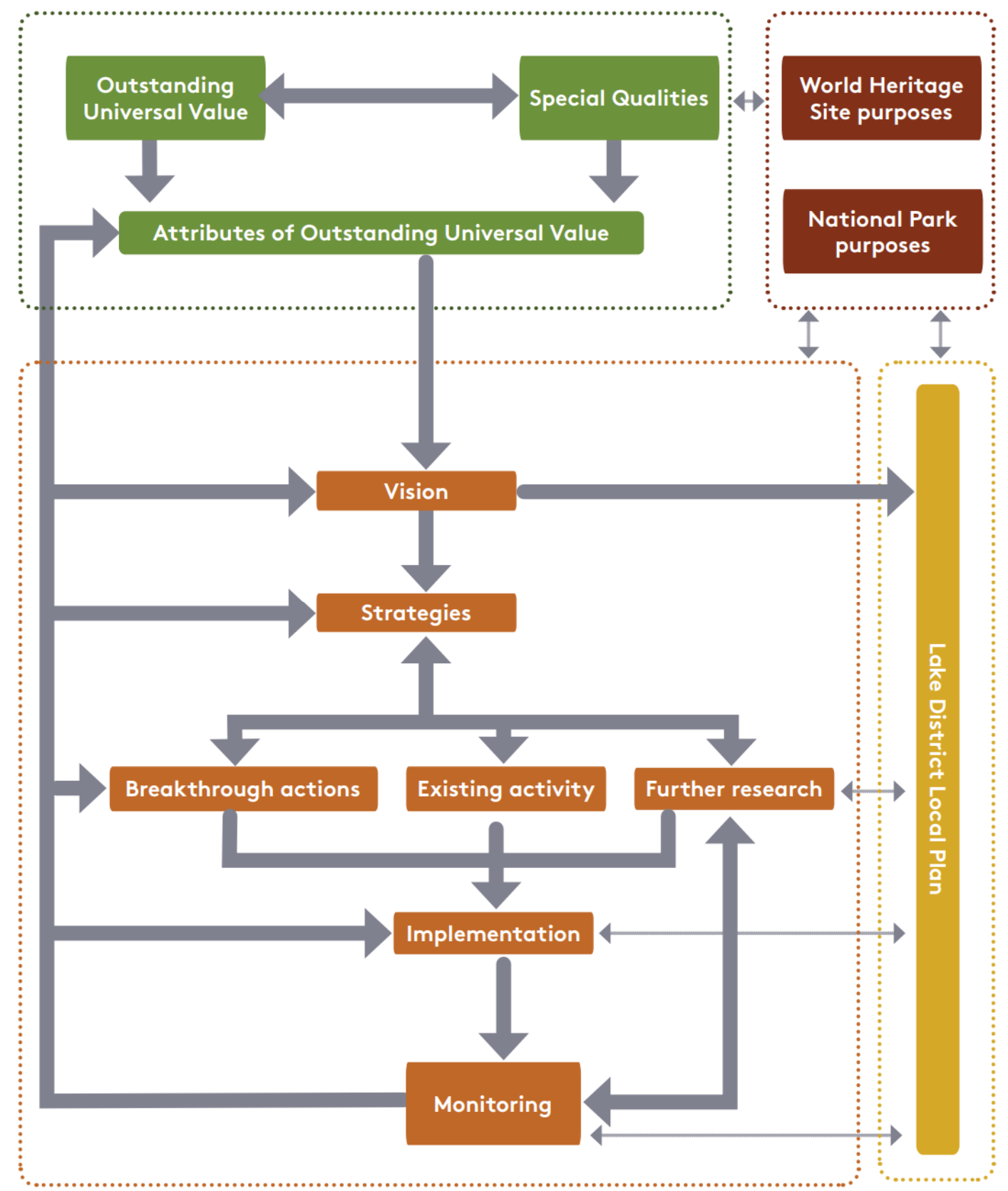

Figure 4. Overview of the Partnership Plan. Source: LDNPP, 2015, p 9. 




Figure 5. Internal structure of the LDNPA (in blue) and related linkages to the Partnership (in green). Source: author. 


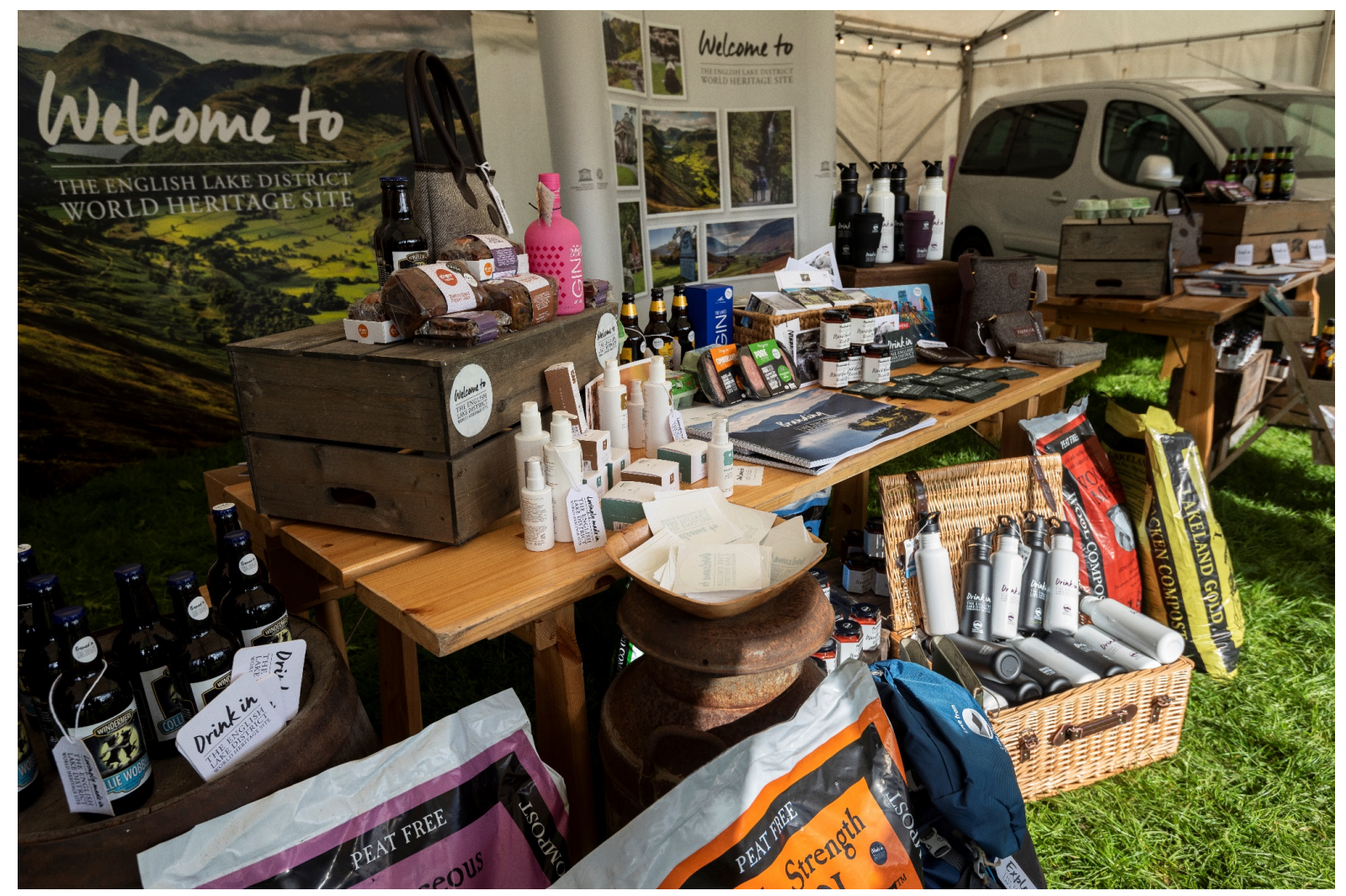

Figure 6. Display launching the English Lake District World Heritage brand at the

Westmoreland Show. Source: LDNPA, 2018c 
Farming THE ENGLISH LAKE DISTRICT WORLD HERITAGE SITE

Lovingly made in THE ENGLISH LAKE DISTRICT WORLD HERITAGE SITE
Invest in THE ENGLISH LAKE DISTRICT WORLD HERITAGE SITE



THE ENGLISH LAKE DISTRICT WORLD HERITAGE SITE
Welcome to THE ENGLISH LAKE DISTRICT WORLD HERITAGE SITE

Protecting THE ENGLISH LAKE DISTRICT WORLD HERITAGE SITE

Figure 7. Examples of the wordmark with sector messaging. Source: LDNPP, 2018c: p.

20. 




Figure 8. Free public transport promoting World Heritage Day, 2019. Source: Alex McCoskrie. 


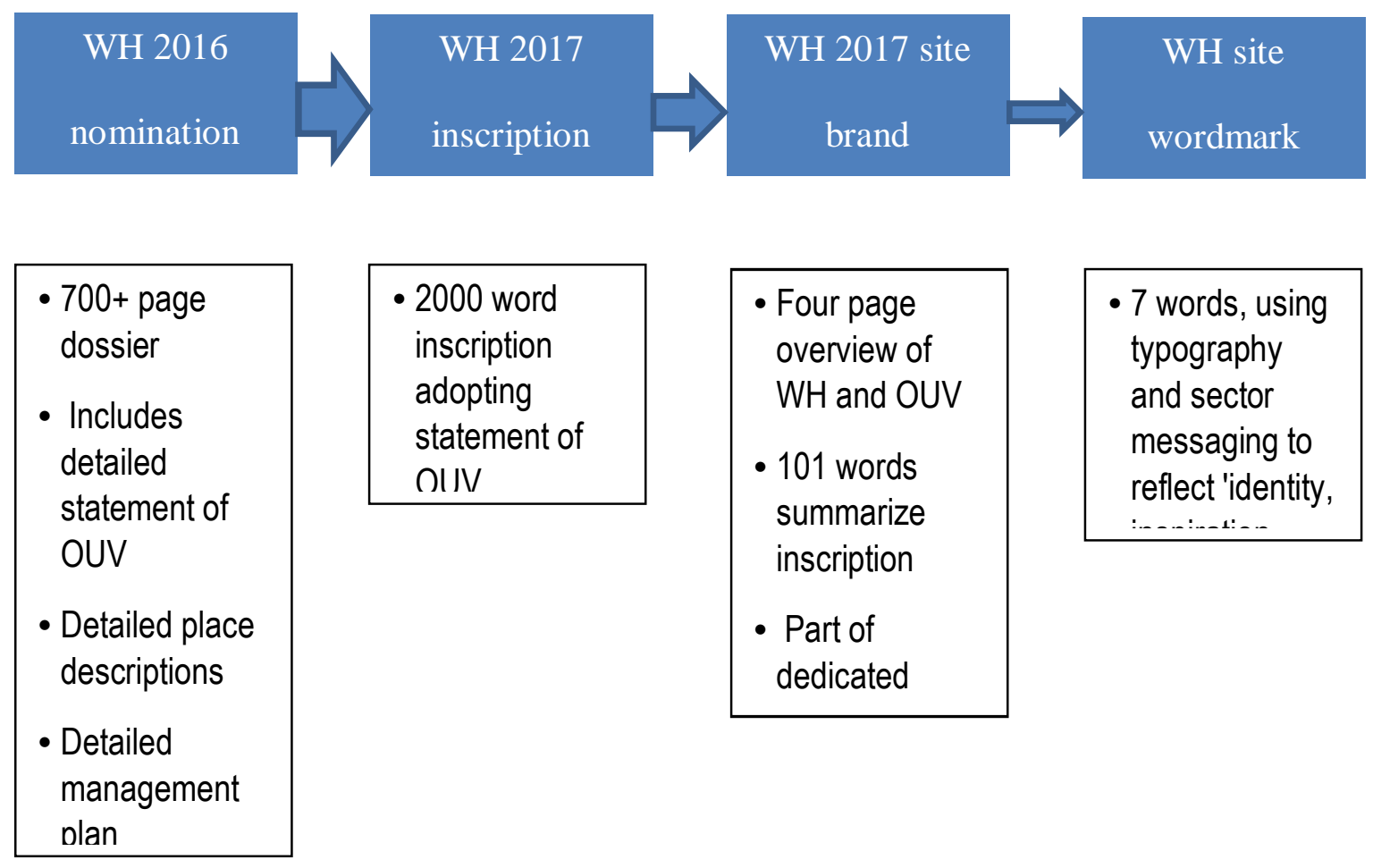

Figure 9. Communication of World Heritage cultural landscape identity, from initial research and nomination through to the brand guideline summary and wordmark. Source: author. 


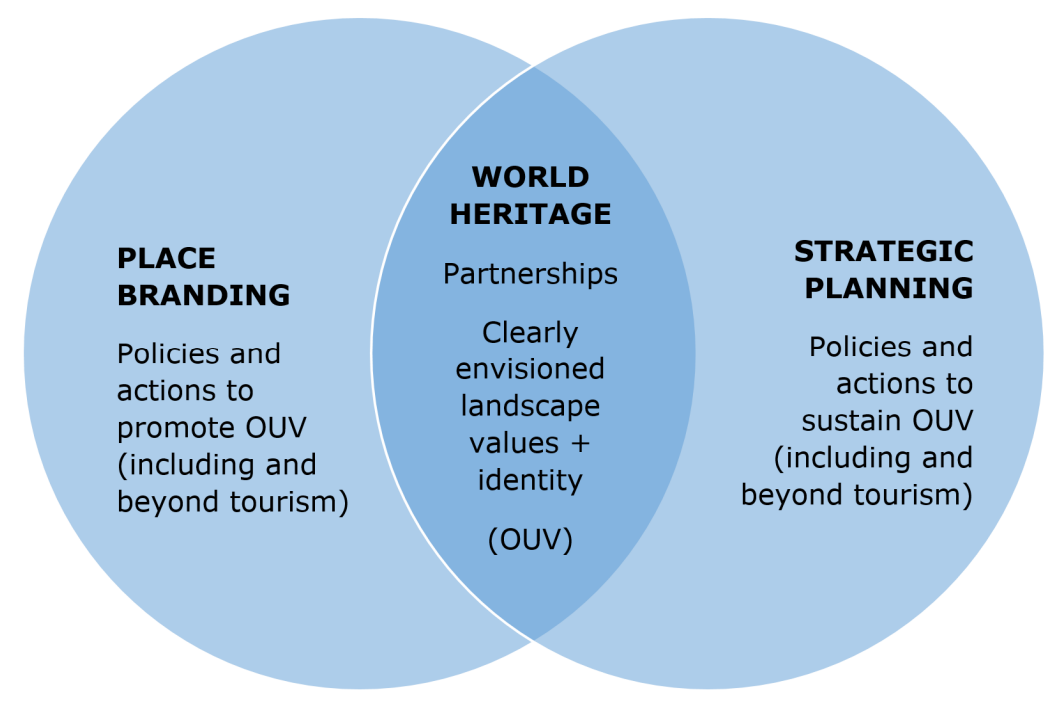

Figure 10. A theoretical model for World Heritage inscription, where becoming a WHS operates as a shared motivating factor that leads to aligned strategic planning and place planning processes. Source: by author. 